HID 45 (2018)

\title{
LEYES INTEMPESTIVAS, CÓDIGO PENAL E IMÁGENES DE LA SIMONÍA ${ }^{1}$
}

UNTIMELY LAWS, CRIMINAL CODE AND IMAGES OF THE SIMONY

JuLiáN GÓMEZ DE MAYA

Universidad de Murcia

gomezdemaya@um.es ORCID: https://orcid.org/0000-0002-0143-2134

RESUMEN: La superación del Antiguo Régimen se resuelve en un complejo, poliédrico proceso pleno de facetas y aristas. La legislación contra el crimen de simonía, verbigracia, penetra en el siglo XIX sostenida aún dentro del ordenamiento español; por supuesto, la tendencia laicizadora que característicamente opera en el proceso codificador supondrá el retraimiento en su represión, pero de alguna manera, entre tradición y reformismo, su objeto quintaesenciado va a buscar otras formas acreedoras al interés punitivo del Estado liberal: los nombramientos ilegales mediante cohecho.

PALABRAS ClAVE: laicización jurídica; codificación penal; clasificación delictiva; simonía; nombramientos ilegales; cohecho.

ABSTRACT: The overcoming of the Old Regime is resolved in a complex, polyhedral process full of facets and edges. The legislation against the crime of simony, for example, penetrates into the $19^{\text {th }}$ century still sustained within the Spanish legal system; of course, the laicizing tendency that characteristically operates in the codifying process will suppose the retreat in its repression, but in some way, between tradition and reformism, its quintessential object was going to look for other forms that are worthy of the punitive interest of the liberal State: illegal appointments through bribery.

KEYWORDS: legal secularization; penal codification; criminal classification; simony; illegal appointments; bribery.

Recibido: 23-4-2018; Aceptado: 6-6-2018; Versión definitiva: 11-6-2018.

1. Este trabajo se encuadra dentro del proyecto de investigación "El crimen en la doctrina jurídica europea: espacio común y singularidades territoriales", financiado por la Fundación Séneca, ref. 19208/PI/14.

Copyright: (C) Editorial Universidad de Sevilla. Este es un artículo de acceso abierto distribuido bajo los términos de la licencia de uso y distribución Creative Commons Reconocimiento-No-ComercialSinObraDerivada 4.0 (CC BY-NC-ND 4.0) 
La metafísica - dice el maestro- es eterna, y pasa á través de los siglos con distintos nombres, con distintos disfraces. Hoy se habla mucho de la sociología... ;La sociología!... ;Nadie sabe lo que es la sociología! ¿Existe acaso? Hemos conocido la teología, que hablaba de todo, que lo examinaba todo; la guerra, la simonía, la colonización, la magia, el matrimonio, todo... (Azorín, La voluntad).

\section{LA LEGISLACIÓN REAL EN LOS ALBORES DEL SIGLO XIX}

Entre los Hechos de los Apóstoles se nos refiere la historia de aquel Simón el Mago evangelizado por Felipe en la ciudad de Samaria: "Simón, al ver que mediante la imposición de las manos de los apóstoles se confería el Espíritu Santo, les ofreció dinero [...]"2 a trueque de que le transmitiesen poder de tanto relumbre. Con el precedente en el Antiguo Testamento de Guejazi o Giezi, el siervo del profeta $\mathrm{Eliseo}^{3}$, la contestación ahora de Simón Pedro a su antagónico tocayo quedaría como la primera proscripción de semejantes pretensiones o conductas:

Perezca tu dinero y tú con él, porque has creído que el don de Dios se compra con dinero. No tienes parte ni herencia en esto, porque tu corazón no es recto delante de Dios. Arrepiéntete, pues, de tu maldad y ruega al Señor, por si puede ser que te sea perdonado el pensamiento de tu corazón; pues veo que estás en la amargura de la hiel y en los lazos de la iniquidad ${ }^{4}$.

De entonces acá, tenaz ha sido el reproche canónico ${ }^{5}$ contra manera tal de sacrilegio consistente, según acaba de verse, en la permuta de una cosa espiritual por otra temporal o, con mayor latitud, en el designio de extraer lucro material de los bienes puramente espirituales: oficios y beneficios, indulgencias y reliquias..., pudiendo desplegarse mediante una enorme casuística en cuanto a estrategias comisivas: no obstante, el comercio con la profesión u ordenación religiosa y con los diferentes ministerios y dignidades de la Iglesia pronto constituyó el ápice más visible, el más escandaloso de cara a la comunidad, en tal medida que el concepto de simonía habría de ceñirse vulgarmente -solo vulgarmente- a más angostos límites, tomándose en una suerte de metonimia la parte por el todo.

Empero, tampoco ha faltado su castigo por las leyes seculares del rey, nuclearmente en las Siete Partidas, la primera de las cuales reserva un título íntegro,

2. La Santa Biblia, p. 1283 (He 8, 18-19).

3. La Santa Biblia, pp. 412-413 (2Re 5, 1-27).

4. La Santa Biblia, pp. 1283-1284 (He 8, 20-23).

5. Para una sucinta panorámica, acúdase, v. gr., a Montalbán 1720, pp. 16-159; Rieger 1841, t. V, pp. 65-92; Cavalario 1841, t. III, pp. 304-316; Diccionario 1854, pp. 1045-1049; Larraga 1860, pp. 331-337; o Alier 1910, pp. 782-784. 
el vigesimoséptimo, a la represión "De la Simonia en que caen los homes". La funcionalidad supletoria de la magna obra alfonsí, dentro del sistema castellano de fuentes desde el trecentista Ordenamiento de Alcalá y a través de las Leyes de Toro, recala en el siglo XIX mantenida en el seno de la Nueva Recopilación de las Leyes destos Reynos de 1567, para pasar enseguida, año de 1805, a la Novísima Recopilación de las Leyes de España, por cuyo conducto se sostendrá en vigor hasta casi mediar la centuria. Otra ley de la misma partida, pero en su título concerniente a los clérigos, trata "De los juicios que pertenescen á santa eglesia por razon de pecado", donde se hace asiento, junto a herejía, usura, perjurio, adulterio y otros pecados, de cómo los pleitos que nacen de simonía "[...] se deben juzgar et librar por juicio de santa eglesia"7. Ahora bien, como al propio tiempo hay establecida represión real, los artífices de Los Códigos españoles concordados y anotados, con apoyo sobre el principio que asoma en una ley del mismo título a cuyo tenor "qualquier que contra esto feciese sin la pena que meresce haber segunt manda santa eglesia, débegela dar el rey segunt su alvedrio catando qual es el yerro", llegan a la siguiente inferencia:

Cuando á un delito corresponde una pena canónica, y al mismo tiempo una pena secular, que deberá ser impuesta por la jurisdiccion secular, se formalizan indispensablemente dos juicios, que no pueden acumularse por su naturaleza, el uno en el fuero eclesiástico para la imposicion de la pena canónica, y el otro en el fuero secular para el castigo correspondiente. La razon es, porque el reo debe sufrir dos penas, satisfaciendo á dos sociedades diversas é independientes, la Iglesia y el Estado ${ }^{9}$.

Esto es: además de la pena canónica, la legal -concluyen-. Aquella comprende en síntesis, o puede hacerlo, excomunión y entredicho, privación de temporalidades al religioso, un año de reclusión, nulidad del acto concesivo y desposeimiento del beneficio, así como inhabilitación ulterior e infamia perpetua ${ }^{10}$; esta otra redunda en las mismas consecuencias privativa e inhabilitante -destitución del empleo y veto para alcanzarlo nuevo-, en el efecto infamatorio y acumula la pérdida doblada de la dádiva o promesa y un extrañamiento por diez años. De cierto, media alguna distancia de uno a otro correctivo y la antedicha interpretación exhibe toda lógica o suficiencia técnica: ni el rey puede excomulgar ni ningún obispo desterrar del reino...; pero tal vez el desenvolvimiento de esta doble regulación no resultase tan razonable ni tan compenetrado: partamos de la Práctica criminal de Gutiérrez, donde leemos que "sobre la simonía no puede caber duda en que es delito mere eclesiástico" "11, al margen de los de fuero mixto; no solo eso, sino que,

6. Las siete Partidas del Rey Don Alfonso el Sabio, cotejadas con varios códices antiguos por la Real Academia de la Historia 1807, I.17.

7. Las siete Partidas 1807, I.6.58., y así parece desprenderse por igual de I.17.12.

8. Las siete Partidas 1807, I.6.62.

9. Los Códigos españoles concordados y anotados 1847/51, t. I, p. 146.

10. V. gr., Perez y Lopez 1791/98, t. XXVII, pp. 356-362; Galilea 1846, pp. 319-321.

11. Gutiérrez 1824, t. I, p. 56. 
tras repasar los cánones pertinentes, se contenta con la simple alusión, sin más extracto, a la normativa alfonsí, en la cual -conforme a lo que arriba queda visto-

[...] se observa mucha conformidad con lo dispuesto en el derecho canónico. Por esta razon, como tambien porque el conocimiento de la simonía corresponde privativamente á los jueces eclesiásticos [...], y las disposiciones del citado titulo se resienten de su antigüedad, hemos tenido presente al hablar de la simonía el derecho canónico con preferencia al nuestro ${ }^{12}$.

Asimismo, Elizondo en su Práctica universal había ya asignado en exclusividad jurisdiccional este que conceptúa "[...] contrato prohibido por el Derecho Positivo Eclesiástico, y no Divino, [...] como contra los Teólogos llevan los Canonistas": por lo tanto, "de estas causas de simonía puramente conoce el Juez Eclesiástico, en cuyo delito puede ser acusador aun el esclavo"13. Por igual, el Febrero novísimo de Tapia entiende que en este yerro, entre los atroces ó atrocísimos, "están [...] sujetos los seglares al fuero eclesiástico [...]", quienes asimismo podrán acusar en tal instancia al clérigo, pues "estas causas son meramente eclesiásticas, y de ellas no puede conocer el juez secular"14. Es la postura también de José María Álvarez al exponer las Instituciones de Derecho real de Castilla $y$ de Indias: delito meramente eclesiástico, de conocimiento privativo junto a la herejía ${ }^{15}$; la de Escriche en su Diccionario ${ }^{16}$, Valle Linacero en sus Leyes penales vigentes $^{17}$, La Serna y Montalbán en sus Elementos ${ }^{18}$ o, sin referencias civiles, el Febrero aumentado ${ }^{19}$, etcétera.

El comentario de Álvarez Posadilla, en la respectiva Práctica criminal, se conduce con menos rotundidad, aunque a la postre termina brindando idéntica solución: "parece en el modo de hablar de la ley que son del privativo conocimiento, pero no lo dice expresamente", mas, de hecho, "la práctica ha declarado la ley dexando de privativo conocimiento solo simonía y el adulterio [...]" en alguno de sus supuestos ${ }^{20}$, con lo cual la infracción simoniaca quedaría, siquiera tan solo en fuerza de la práctica, exorbitante al género mixti fori. Por el contrario, las Instituciones del Derecho civil de Castilla de Asso y Manuel catalogan la simonía entre los delitos públicos, que son "[...] todos los que causan escándalo, contra los quales puede el juez proceder de oficio" ${ }^{21}$. Más a las claras: Vizcaíno en su Práctica sí da por "supuesto que puede la Justicia Real conocer de los delitos privilegiados de los Clérigos ú otros qualesquiera Eclesiásticos" ${ }^{22}$. Tomado todo en conjunto,

\footnotetext{
12. Gutiérrez 1824, t. III, p. 19.

13. Elizondo 1779, t. I, pp. 46-47.

14. Tapia 1837, t. VI, pp. 21, 169, 210.

15. Álvarez 1827, t. IV, p. 11.

16. Escriche $1838 / 45$, t. III, p. 476.

17. Valle Linacero, Chavarría y Montoya 1840 , p. 49.

18. Gómez de la Serna, Montalbán 1843, t. II, p. 316.

19. García Goyena, Aguirre 1842, t. VII, p. 206.

20. Álvarez Posadilla 1802, t. II, pp. 70-71.

21. Asso y del Río, Manuel y Rodríguez 1805, pp. 220-221, con p. 239.

22. Vizcaíno Pérez 1797, v. I, p. 56.
} 
una azarosa apreciación de la simonía en clave de uno de los "asuntos que jurídicamente quedan definidos como 'res mixtae', que merecen la atención del Estado y de la Iglesia"23, fundada esa persecución por los tribunales del rey en el amplio elenco de competencias relacionadas con la vida civil que aparejaban los cargos eclesiásticos ${ }^{24}$, solo parece entendible desde el punto de vista regulativo y del interés punitorio - "por el perjuicio que hacen á la sociedad", en palabras de Tapia ${ }^{25}$, pero no tanto en un sentido de concurrencia abocada al conflicto o, cuando menos, a la celosa cuanto suspicaz vigilancia de las propias fronteras jurisdiccionales, pues parece que este deslinde, al menos en la práctica -informaba Posadilla-, se fijó con nitidez a favor del fuero de Iglesia. Solo a modo de apunte orientativo, si antes de abandonar la cuestión consultamos la prestigiosa autoridad de Gregorio López, le veremos acudir a su vez a las de Juan Andrés y el Abad Panormitano, en cuyo concepto es la simonía, en cuanto manifestación heretical, crimen meramente eclesiástico, si bien abunda acto seguido en las opiniones de Juan de Ímola y Juan de Ana, quienes admiten castigo secular, pero siempre tras previa sentencia declaratoria en lo eclesiástico ${ }^{26}$, sin el dúplice juicio indispensablemente que nos han abonado los anotadores de Los Códigos españoles: comoquiera, a pocas dudas se presta el sentido de la glosa...

Mas dejémoslo así y vayamos adelante: baste la constancia de que, cuando pueda envolver la simonía alguna controversia -engallada en el regalismo-acerca de su conocimiento y substanciación jurisdiccional, sí que en el aspecto normativo se hace ostensible la convivencia de ambos sistemas, no entrañando materia únicamente de cánones, sino a la par de leyes. Y más allá -más acá- del código ducentista, hay al menos otra (con concomitancias previas y posteriores) no solo pertinente, sino en extremo substanciosa o significativa: se trata de cierta pragmática, promulgada en 1614 por Felipe III e inserta en la Nueva Recopilación, cuyo encabezamiento ya resulta bien indicativo de la mezcolanza que en torno al objeto expande civilmente la ofensiva antisimoniaca: "Que las Prelacías, Beneficios, i Encomiendas, i todos los demás oficios, que son del Patronazgo, i Provision Real, nadie los pretenda por dadivas, ó promesas; i los que lo contravinieren, assi Eclesiasticos, como Seglares, incurran en las penas en esta lei contenidas"; pero afinemos en lo posible ese objeto -desbordante ahora de los dones divinos- en el despliegue de la ley:

[...] todos, i qualesquier pretendientes de gobiernos, i oficios de administracion de Justicia, i de prelacias, Dignidades, Prevendas, i Beneficios Eclesiasticos, Abitos, $i$ Encomiendas de las Ordenes Militares, $i$ otros qualesquier oficios, i Beneficios, Seculares, ó Eclesiasticos, i comisiones de qualesquier generos, ó calidad que sean, cuya provision, ó presentación á Nos pertenezca, [...] que por sí, ó por interpuestas personas, directé ó indirecté, que se ayan valido, ó valieren de favores adquiridos,

23. Maqueda Abreu 1997, p. 1571.

24. Mapelli Caffarena, García Benítez, notas a Echebarría y Ojeda 2006, pp. 86-87.

25. Tapia 1837, t. VI, pp. 152-153.

26. López, glosas a Las siete Partidas del sabio Rey don Alonso el nono 1555, f. 69r. 
i grangeados por medio de dadivas, ó promesas en poca ó mucha cantidad, i que por semejantes medios consiguieren, ó intentaren adquirir el oficio, ó beneficio, ó qualquier cosa de las de suso referidas [...].

$\mathrm{Y}$ a tales pretendientes, junto a otorgantes y mediadores, les apronta, "por el mismo hecho, sin que sea necessaria otra declaracion", las penas de inhabilidad e incapacidad para retener o conseguir lo ambicionado, la nulidad de la provisión ("la qual desde luego declaramos por ninguna, por defecto de nuestra intencion, $\mathrm{i}$ voluntad") y lanzamiento por diez años de estos nuestros Reinos; específicamente a los eclesiásticos se les prescribe la pérdida de temporalidades, de naturaleza "[...] i sean avidos por estraños destos Reinos"27. Aquel encabezamiento de la promulgación en la Castilla de los Austrias, al transferirse a la Novísima, dentro de su título "De los pretendientes y forasteros de la Corte", se trocará en equivalente "Prohibicion de pretender oficios algunos eclesiásticos y seculares por medio de dádivas y promesas: modo de probar este delito; y pena de los que en él incurran"28 - circunscritos aquellos a los de alguna manera mediatizados por la voluntad regia $^{29}$-, cuyo mandato viene reforzado por cédula de Carlos IV para "Observancia de la ley precedente, prohibitiva de solicitar empleos y destinos por medios reprobados", dada en 1795 a raíz "[...] de una causa formada de mi órden contra varias personas sobre estafas, con el fingido pretexto de sacar empleos"30. Con precedencia, algunas leyes tardomedievales y premodernas se habían ya enderezado, dentro de un mismo campo, contra el crimen de ambitu o ambiciosa postulación para procuraciones a cortes (Juan II en Valladolid y 1347), oficios concejiles (el mismo monarca en Toledo y Guadalajara el año 1436) y oficios de jurisdicción (los Reyes Católicos en Madrid y 1494, Carlos I en Valladolid y 1525): también pasan a la Recopilación ${ }^{31}$.

Otras disposiciones de mayor o menor antigüedad agavilladas en aquel novísimo título sobre pretendientes forasteros bordean semejantes cuidados (el ansia y la sed de los oficios que el capitán Fernández de Andrada transformara en materia poética con tan exquisito suceso ${ }^{32}$ ), atentas a "[...] que hay muchos pretensores de oficios, que [...] sin las partes que se requieren, pretenden con mucha importunidad, negociacion y favor [...]" (Felipe II en 1588) y comprometidas en poner algún remedio o coto "[...] á fin de contener del modo posible las importunas é injustas pretensiones" (otra vez el último Carlos en 1799 y 1803) ${ }^{33}$, mas en todo momento con un talante no penal, sino administrativo-procedimental o, en las últimas periferias represoras, de buena policía.

27. Las Leyes de Recopilacion 1772, VIII.26.18 (en Recopilacion de las Leyes destos Reynos 1640, VIII.26.23).

28. Novísima recopilación de las Leyes de España 1805, III.22.3.

29. Ahóndese, v. gr., en Gutiérrez Martín 1967, pp. 100-109; Giménez Carrillo 2011, pp. 301313, más particularmente pp. 310-313.

30. Novísima recopilación, III.22.4.

31. Las Leyes de Recopilacion 1772, VI.7.7, VII.2.7 y 8, VII.3.7.

32. Fernández de Andrada 1993, p. 76 (v. 55).

33. Novísima recopilación, III.22.2 y 14, respectivamente. 
Hasta este punto el repaso de la doctrina dieciochesca ha transitado por los dominios normativos del Derecho común, de las colecciones canónicas a las Partidas, pero se hace preciso comprobar ahora qué tratamiento recibe -cuando lo reciba- esta florescencia de ius regium de parte de esos mismos autores o de otros contemporáneos. Uno de los arriba consultados, José Marcos Gutiérrez, se excusaba antes de su preferencia por el Derecho canónico a la hora de exponer la conculcación simoniaca, alegando atribución privativa al fuero eclesiástico y la conformidad esencial de las anticuadas leyes seculares con aquel; así y todo, no le iba a librar esa precaución de la censura de Tapia en su Febrero novísimo:

Ninguna de estas razones hace disculpable en el señor Gutierrez la omision ó silencio absoluto que guarda acerca de la pragmática del señor Don Felipe III [...], en la cual no solo prescribe aquel Soberano penas contra este delito, sino que declara tambien el modo de probarle. Otros delitos hay, como el de heregía, cuyo conocimiento pertenece a los tribunales eclesiásticos, y sin embargo la ley civil tiene penas impuestas contra ellos, bajo cuyo concepto debe tomarlas en consideracion el que trata de materias criminales, como lo hace el mismo señor Gutierrez en la de heregía. Cuando por esta conoce el tribunal eclesiástico, habiendo de imponerse pena de sangre, entrega al reo al brazo secular; y he aqui como es necesario hacer conocer á un tiempo las disposiciones del derecho canónico y civil. El primero fulmina sus censuras, é impone otras penas correspondientes á la jurisdicción eclesiástica, y el segundo suele castigar además con penas de otra clase á los transgresores por el perjuicio que hacen á la sociedad, ó por otras consideraciones ${ }^{34}$.

La Librería de Jueces de Manuel Silvestre Martínez refleja muy bien en 1768 un corrimiento referencial hacia el medio civil en su selección de personal al servicio de la Monarquía: "el que solicita empleo con soborno tiene pena de inhábil para la pretension; y si es cosa Eclesiástica, comete simonía"35, respetada, pues, el área criminológica de siempre, mas expandida ahora mediante ese deslizamiento hacia otras cosas ya no eclesiásticas que Vilanova y Mañes designará como imágenes de la simonía ${ }^{36}$.

Hay autores de los hasta aquí atendidos u otros a caballo entre las centurias dieciochesca y decimonónica que desdeñan la legislación alfonsí y tan solo hacen mérito ya de la pragmática filipina de 1614 con sus adyacencias sectoriales: así, Echebarría $^{37}$ en 1791, Dou y Bassols ${ }^{38}$ atento al crimen de ambitu en 1800, Tapia, apenas invocando la parcelación de jurisdicciones según las Partidas $^{39}$ ya hacia 1830, o Valle Linacero ${ }^{40}$ en 1840; en cambio y sin arrumbar este Libro del fuero de las leyes en su ordenación material, Asso y Manuel ${ }^{41}$ en 1771 o Vizcaíno en 1797

34. Tapia 1837, t. VI, pp. 152-153.

35. Martínez 1791, t. I, p. 74.

36. Vilanova y Mañes 1807, t. III, p. 107.

37. Echebarría y Ojeda 2006, pp. 86-87.

38. Dou y de Bassóls 1800/02, t. VII, pp. 224, 285-286.

39. Tapia 1837, t. VI, pp. 154-155, 210.

40. Valle Linacero, Chavarría y Montoya 1840, pp. 49-50.

41. Asso y del Río, Manuel y Rodríguez 1805, pp. 221, 239. 
acopian ambas fuentes; otros no dan traslado o noticia sino del pertinente título en el corpus tardomedieval: Berní ${ }^{42}$ en 1748, Febrero ${ }^{43}$ en 1769, Cornejo ${ }^{44}$ en 1779, Posadilla $^{45}$ en 1794, Pérez y López ${ }^{46}$ en 1798 , Gutiérrez ${ }^{47}$ en $1806 \ldots$; los hay, en fin, que no descienden al ámbito normativo y permanecen en el de la erudición jurídico-filosófica o comedidos a la regulación canónica, como Elizondo ${ }^{48}$ en $1764 \mathrm{o}$ Escriche $^{49}$ hacia 1845. Sala ni menciona en 1803 el de referencia al revisar los delitos de fuero eclesiástico que además “[...] tienen en nuestras leyes establecidas sus penas", ni aun entre los que infaman de derecho ${ }^{50}$; tampoco García Goyena en su Código criminal español segun las leyes y practica vigentes de $1843^{51}$.

Hacia la segunda mitad del siglo XVIII, los jurisconsultos prácticos continúan en su mayoría recogiendo en sus prontuarios la vetusta legislación real dada contra simoniacos y giezitas en paralelo al acervo canonístico. Menos apegados a la tradición o más perspicaces para sorprender el reflejo de la mudanza de los tiempos y las prioridades en un ordenamiento que está a la sazón por alumbrar un novedoso sector criminológico, otros cuantos se fijan en la pragmática filipina, acumulándola o incluso confiriéndole todo el protagonismo con prescindir en este punto de cualquier lastre escolástico y bajomedieval en alarde de una agilidad que resulta más de agradecer confrontada con aquel anquilosamiento: quizás adolezca este reproche de alguna justicia, pues, al fin y al cabo, lo que hay es mera transmisión del Derecho que continúa formalmente rigiendo, aunque acaso a costa de traicionar así en algo o en mucho el tremolado espíritu práctico... Lo que sí se nos hace ya chocante, para las ilustradas eminencias donde se forjan las leyes, es que comparezca aún la simonía entre los delitos contra la Religión en el Plan de Código Criminal de 1787, primer fruto en agraz del método codificador merced a los ilustrados trabajos de la Junta de Legislación sobre los extractos legales de Lardizábal con miras a poner al corriente la obsoleta exuberancia recopilada ${ }^{52}$.

\section{LA CODIFICACIÓN DE 1822}

Ni la comisión redactora del Proyecto de Código Penal de 1821 ni las instituciones e ilustrados particulares que sobre él evacuaron informes ni los representantes parlamentarios de la nación en el trance de debatir el articulado en las Cortes consideraron la posibilidad de tipificar la simonía: únicamente aquella, al

\footnotetext{
42. Berní 1749, pp. 63-64.

43. Febrero $1769 / 81$, prt. $1^{\text {a }}$, t. II, p. 388.

44. Cornejo 1779, pp. 558-559.

45. Álvarez Posadilla 1802, t. II, pp. 70-71.

46. Perez y Lopez 1891/98, t. XXVII, pp. 363-370.

47. Gutiérrez 1824, t. III, p. 19.

48. Elizondo 1779, t. I, pp. 46-47.

49. Escriche 1838/45, t. III, p. 475.

50. Sala 1832, t. II, pp. 86-94.

51. García Goyena 1843, t. I, pp. 128-151.

52. Compruébese en Casabó Ruiz 1969, p. 332.
} 
presentar su propuesta a la cámara, consignaba cómo, en su cruzada contra jurisdicciones especiales y privilegios de inmunidad, había de reconocer, no obstante, el fuero eclesiástico, mas reducido a sus justos términos, “[...] quedando ilesa y en su vigor la autoridad y jurisdiccion de los Prelados respecto de las culpas y delitos que los eclesiásticos cometiesen contra su estado, contra la disciplina y sagrados cánones" 53 . Por lo demás, interesan otras dos referencias de los comisionados: una, a tantas leyes y títulos intempestivos en el dia como recientemente acababa de revalidar la Novísima, pero que, por el contrario, “[...] no deben ocupar ningún sitio ni insertarse directamente en un buen Código criminal"s4; la segunda, a otro género de delitos también al parecer expulsos de la naciente ley pero porque, ahora, "[...] están comprendidos ó embebidos en otras disposiciones del proyecto" Lo cierto y verdad es que ya nada recuerda a la pecaminosa simonía en el capítulo reprobatorio "De los delitos contra la religión del Estado" (pero -recuérdese- tampoco había figurado entre los crímenes de lesa majestad divina más que en las Partidas, no así en las recopilaciones) ni en ningún otro.

De no aproximarse las décadas ominosa y de las regencias por la menor edad isabelina y aun algo más, se diría que la conculcación simoniaca culminaba aquí su metamorfosis, de la cual la pragmática de Felipe III con sus antecedentes habría representado un estadio intermedio, arribando a los terrenos civiles o laicos del nepotismo, compraventa de oficios y similares corruptelas en la recluta de operarios para la actuación estatal: permanece el elemento objetivo, laicizados los sujetos con reemplazo del andamiaje teológico por aplicaciones de cálculo políticocriminal. Así, en el frutecido Código, “[...] el funcionario público, de cualquiera clase, que encargado de proveer alguna dignidad, cargo, oficio ó empleo público, ó comision del Gobierno, ó de hacer las propuestas para su provision, ó de intervenir en ello por razon de su destino" podrá representar el sujeto activo de una conducta típica conducente a que "[...] haga, en virtud de algun soborno ó cohecho, que la provision ó propuesta recaiga en favor de persona determinada, por mas acreedora que sea", y se verá afligido al cabo con las sanciones del prevaricador -pérdida de empleo, sueldo y honores, imposibilidad de obtener nuevo cargo público-, infamia y reclusión de hasta cuatro años; en cuanto a "los que hagan soborno, cohecho ó regalo [...]" se les apareja una reclusión de hasta tres años ${ }^{56}$, "pero los que hayan sobornado, cohechado ó regalado, ó procurado sobornar, cohechar ó regalar con el fin de obtener el ser propuestos para dignidad, cargo, oficio ó empleo público [...]" -y aquí se allega un ya tradicional plus de quebranto inhabilitatorio- " $[\ldots]$ sufrirán, ademas de las penas prescritas [...], la de perder lo que hayan obtenido por tal medio, y no poder obtener cargo alguno público en adelante", salvo "si el soborno en estos casos no hubiere sido aceptado [...]", saldándose entonces la cuestión con un arresto de seis meses como máximo tras ser reprendido en la

53. Diario de las Sesiones de Córtes. Legislatura Extraordinaria, t. I, apd. al nº 38, ses. 1-XI1821, p. 484.

54. Diario de las Sesiones..., t. I, apd. al no 38, ses. 1-XI-1821, p. 483.

55. Diario de las Sesiones..., t. II, nº 60, ses. 23-XI-1821, p. 927.

56. Código Penal de 1822, art. 455. 
sentencia, multa por el valor equivalente y privación del nombramiento con veto de acceso a otro cargo en lo sucesivo ${ }^{57}$. Todavía, otro precepto del título preliminar dejaba establecido que "en todo delito cometido por soborno, cohecho ó regalo, y en cualquiera en que intervenga alguna de estas cosas [...]"-recelado el resquicio por el que acierte a escapar la provisión ilícita-, "[...] se impondrá al sobornador y al sobornado de mancomun una multa equivalente al tres tanto de lo dado ó prometido, sin perjuicio de las demás que prescriba la ley" ${ }^{\prime 2}$. Visto lo visto, bien cabe preguntarse por la genealogía del novedoso tratamiento: si responde a originalidad de diseño, si consiste en atinada derivación evolutiva desde aquella pragmática del tercer Felipe o si es ascendiente ultrapirenaico lo que revela.

A la mira del ordenamiento más aducido por los parlamentarios ${ }^{59}$, en el Código francés de 1791 no se vislumbra nada análogo entre los "Crímenes de los funcionarios públicos en el ejercicio de los poderes que les son conferidos" (por supuesto, tampoco hay crímenes de orden religioso) ${ }^{60}$. El napoleónico de 1810 tampoco precave los nombramientos ilegales en concreto ni describe eventuales desmanes del funcionario sobornado sino en forma genérica, mas entre los móviles del cohechador sí alista el de obtener places, emplois, adjudications, entreprises ou autres bénéfices quelconques ${ }^{61}$ : con todo, no abona enlace tan tenue ninguna filiación para el protocódigo hispano, en desmentido del seguimiento general del modelo codificado francés respecto del cohecho ${ }^{62}$. Sin embargo, otras conclusiones pudiera arrojar el examen de los tres pensadores cuyo influjo -al menos, la consultareconocen los comisionados de 1821 en su composición del proyecto que elevan a la cámara: "la comision confiesa ingénuamente que ha tomado muchas cosas del Código francés, así como de las obras de Bentham, de Filangieri, de Bexon, y de los demás que ha tenido á la mano" "63, tres juristas - un inglés, un italiano y un francés- que, a diferencia de sus coevos hispanos, se presentan forjadores de sendos sistemas que vienen a postular como ruptura con la inercia legislativa del Antiguo Régimen.

La Ciencia de la legislación de Gaetano Filangieri (1752-1788), cuyo original data de 1780, aparece traducida y publicada en castellano tan madrugadoramente como el año 1787, el mismo del frustrado Plan de Código Criminal, con el que no discrepa en este particular tanto como en un principio sería de suponer. Pese a que "los delitos contra la divinidad no deben estar sujetos á la sancion de las leyes, sino cuando llegan á ser delitos civiles" "64, aprecia el napolitano que, en cuanto violación de un pacto social acerca del credo común o colectivo, sí lo es -y el mayor-aquel

57. Código Penal de 1822, art. 460.

58. Código Penal de 1822, art. 89.

59. Hojéese Ramos Vázquez, Cañizares Navarro 2014, pp. 193-270.

60. “Código Penal francés de 1791” 2009, pp. 487-517.

61. Código penal francés, traducido al castellano por orden de S. M. el emperador Maximiliano I 1866, p. 43 (art. 179).

62. Iñesta Pastor 2011, p. 677.

63. Diario de las Sesiones..., t. II, nº 60, ses. 23-XI-1821, p. 924 . Váyase a Antón Oneca 1965, p. 270 .

64. Filangieri $1821 / 22$, t. IV, p. 151. 
"[...] que substituye á la idea de las perfecciones del Sér supremo la de un ente avaro que pone precio á sus gracias, vende su justicia, y solo se aplaca con dádivas y ofertas" $"$, o sea la simonía, impiedad que "[...] convierte en un instrumento de delitos"66 la Religión: le seguirán en orden decreciente de gravedad el proselitismo herético o ateo, el desprecio injurioso del culto público y de la creencia del país, la promulgación del fanatismo, el sacrilegio, el perjurio y la blasfemia ${ }^{67}$, pero la transgresión simonica "[...] debe colocarse en primer lugar, y ser castigada con mas rigor [...]. Esta razon es el interes que puede haber en promover la doctrina de esta expiacion errónea" ${ }^{6}$, es decir el añadido interés crematístico. Y, aparte de tamaña instrumentalización burguesa del hecho religioso en aras del orden y la homogeneidad social, descendiendo a cotas profanas, el cohecho encuentra en Filangieri un delineamiento monopolizado por los atropellos de índole forense ${ }^{69}$.

En su Teoría de las penas y de las recompensas, vertida a lengua española con simultaneidad a los debates parlamentarios sobre el proyecto de Código de 1821, constataba Jeremy Bentham (1748-1832) en cuánta medida, por encima de las de los jueces y los militares, "la venalidad que ha escitado las mas vivas reclamaciones, es la de los empleos eclesiásticos; porque se ha hecho de ella un pecado particular, y de este una especie de delito con el nombre de simonía"; pero tan solo -a su entender- "siendo la iglesia católica infalible en los paises católicos, ha podido decir que este acto era un pecado", una cosa ha llevado a la otra "y las leyes han hecho de este pecado un delito", cuando en realidad y con juicio ecuánime, “[...] vemos al instante que nada tiene que ver con la acción de Simon Mago", toda vez que en los Hechos de los Apóstoles "[...] se acaba su historia, sin que se hable de haberle castigado" "70 más allá del apóstrofe petrino; esto, por lo que concierne a su fundamento, puesto que, si luego se analiza la pertinencia de la intervención punitiva desde el punto de vista de la utilidad, medular en el pensamiento benthamiano, "en cuanto á las leyes llamadas anti-simoniacas, de nada sirven, porque [...] estas leyes solo parecen aguijonear el fraude" de recurrir a tercero interpuesto, colocando en definitiva "[...] á los eclesiásticos en un desfiladero peligroso entre la mentira y el interes" $"$. Ahora bien,

$[\ldots]$ pero nosotros [...] no examinamos aquí sino el delito legal [...]. Si el objeto de la ley es el de asegurar la esclusion de los indignos, hay medios directos tan naturales como eficaces para ello, y tales son los exámenes públicos para verificar la doctrina y ciencia del candidato, y tal seria la libertad que se diese al público para tacharle por sus costumbres. Estando asi acreditada la capacidad intelectual y moral, debia serle permitido comprar el empleo, ó desempeñarle gratuitamente ${ }^{72}$.

65. Filangieri $1821 / 22$, t. IV, p. 149 .

66. Filangieri $1821 / 22$, t. IV, p. 152.

67. Filangieri 1821/22, t. IV, pp. 149-164.

68. Filangieri $1821 / 22$, t. IV, p. 153.

69. Filangieri 1821/22, t. IV, pp. 210-213.

70. Bentham 1838, t. II, p. 139.

71. Bentham 1838, t. II, p. 140.

72. Bentham 1838, t. II, pp. 139-140. 
Por lo que ya se va viendo, acaso con alguna perplejidad, no blande el jurisconsulto londinense la más mínima repulsa contra la venalidad como mecanismo de selección y acceso a cargos o empleos transcendentes para el común, persuadido en su utilitarismo de que

[...] si la riqueza invade por una parte el patrimonio del mérito, por otra estrecha el terreno del favor, y este es una divinidad mas deshonrada que la riqueza. Pero lo que en particular debe inclinar los políticos recelosos en favor de la venalidad, es que minora la influencia del gobierno; porque cuanto terreno posee, es una conquista sobre la autoridad ministerial. Es corrupcion, si se quiere, pero que sirve de contraveneno á otra mas temible ${ }^{73}$.

Si es un bien el que los empleados se contenten con un sueldo moderado; lo es mayor el que sirvan gratis, y todavía mayor el que consientan en pagar para lograr el empleo en vez de tener sueldo. Este es un raciocinio muy sencillo, pero muy concluyente en favor de la venalidad de los empleos, si se la considera en abstracto. [...] La compra de un empleo es una presuncion de aptitud para obtenerle; y si tiene emolumentos, quizá son ellos el único motivo para desearle; pero si no los hay, se hace por gusto el ejercicio de las funciones, ó por el honor y la autoridad inherentes á él. Es verdad que se puede desear un empleo [...] para sacar de él algun provecho oculto perjudicial al público; pero este es un caso particular cuya existencia debe acreditarse con pruebas ${ }^{74}$.

En coherencia con estos y otros concomitantes argumentos, nada extrañaría, pues, que tales formas de venalidad en los empleos encontrasen vedado el paso a tan personal sistema de principios de legislación y de codificación, pero el método que suele seguir Bentham es clasificarlo todo, siquiera sea para luego desecharlo, como hace al describir, por ejemplo, los delitos reflexivos o los de mal imaginario $^{75}$, así que ahí tenemos, por consiguiente, como uno de los delitos contra la condición del Estado por faltas del poder ejecutivo, el de venalidad de los cargos públicos $^{76}$, si bien deberá ser interpretado - parece que huelga decirlo- a la luz de lo arriba expuesto de su propia pluma. Uno de sus más activos divulgadores en España, Toribio Núñez, explanando durante el período trienal la doctrina del filósofo británico, discurre en el sentido de que

[...] No deberíamos poner este orden de delitos en la escala, porque nuestra Constitucion política no deja á ningun poder, ni á autoridad alguna la facultad de venderlos legalmente, como ha sucedido en otros gobiernos, y aun en el nuestro anteriormente, respecto de las plazas y grados militares; pero el patriotismo militar no sufre ya las injusticias tan opuestas á su pundonor. Sin embargo no estará demas en la escala para acudir á este orden, cuando los sobornos de cualquier género se

73. Bentham 1838, t. II, pp. 138-139.

74. Bentham 1838, t. II, pp. 135-136.

75. Bentham 1834, t. II, pp. 236-237, 243-245.

76. Bentham 1821, pp. 402, 429. 
introduzcan en las provisiones ó en las elecciones ó en las propuestas, y para que se coloquen en el sitio que deban ocupar en el código pena $l^{77}$.

Lo que sí quisiera ver punido Bentham, en el apartado de delitos contra la seguridad interior del Estado, es la formalista conculcación atingente a "autoridades ilegitimas: las que no estan decretadas por las Córtes, ó que no se han nombrado conforme á las leyes"78. también los delitos contra el ejecutivo de "soborno de los Ministros del Gobierno por los Diputados de Córtes ó al contrario por pensiones, empleos ó condecoraciones para sí ó para otros, durante el tiempo de su diputacion y un año despues" (el cual afronta un lucro particular, defraudatorio del fisco y agresor a la interrelación de poderes estatales) y de "presentacion ilegítima de beneficios eclesiásticos de real patrimonio, la que se hiciera por el Rey sin propuesta del Consejo de Estado" (con la misma resultancia atentatoria contra la división de poderes $)^{79}$.. Bien se echa de ver que nada de esto tuvo repercusión en el proceso codificador del Trienio constitucional ni aun en los ulteriores, sí las precisiones de Núñez -recién transcritas- "[...] cuando los sobornos de cualquier género se introduzcan en las provisiones ó en las elecciones ó en las propuestas, y para que se coloquen en el sitio que deban ocupar en el código penal": exactamente, en su segmento de artículos consagrados a sobornos y cohechos ${ }^{80} \ldots$

Por último, Scipion Bexon (1750-1825) diseña en 1807 su Application de la théorie de la législation pénale, ou code de la sureté publique et particulière, en la cual divide las conductas típicas en contraventions et fautes, délits y crimes, según la estructura triunfante en su país desde el Código de $1791^{81}$; pues bien, dentro de la categoría intermedia viene a acoplar el siguiente delito contre la sureté générale et la paix publique, penado con destitución de la plaza ilegítima y reintegro de emolumentos percibidos, así como con multa por el doble del valor de la contraprestación:

Quiconque, parvient à quelques fonctions publiques dans l'Etat, par le moyen de présens ou promesses, de quelque manière que ce soit, envers celui de qui la nomination de la place dépend, ou qui est dans le cas d'y contribuer par sa voix ou son suffrage, ou envers celui que l'on croit pouvoir le déterminer à l'accorder, est déclaré commettre un délit d'usurpation du pouvoir ${ }^{82}$.

Y sigue a continuación una serie de artículos referentes a aquel de qui la nomination de la place dépend, ou qui est dans le cas d'y contribuer; verbigracia, por negligencia:

77. Núñez, comentarios a Bentham 1821, pp. 429-430.

78. Bentham 1821, p. 231.

79. Bentham 1821, pp. 234-235.

80. Cfr. notas 56 y 57.

81. Masferrer Domingo 2003, p. 121

82. Bexon 1807,1 IV, $3^{\text {a }}$ prt., p. 87 (art. 277 , párr. $1^{\circ}$ ). 
Quiconque, occupant dans l'Etat quelque place en chef, qui lui donne le droit de nomination à des places inférieures, qui, par faveur, ou sans s'assurer avec soin de la capacité ou de la probité, aura nommé quelqu'un à une place ou emploi public, dont l'incapacité ou l'improbité seront ensuite reconnues, est déclaré coupable d'un délit de négligence, dans l'exercice du droit d'elire ${ }^{83}$.

Jefe tal movido por favor o sin el exigible cuidado se hará merecedor de una multa y responsable por daños, en su caso con los intereses. Y asimismo, puede el vínculo causal nacer de corrupción, llevada entonces la multa hasta un mínimo de tres veces el valor de la dádiva, con suspensión o interdicción de su propio cargo (de la reincidencia se hace un crimen, con remoción e inhabilitación, más un agravamiento de la sanción pecuniaria $\left.{ }^{84}\right)$ :

Quinconque, dans le cas de l'article précédent, qui, moyennànt un prix reçu ou promis, ou par dons ou promesses, de quelle manière que ce soit, aura disposé d'une place ou d'un emploi quelconque dans l'Etat, en faveur de quelqu'un, qu'il en soit digne ou non, ou l'aura désigné ou secondé pour y parvenir, est déclaré coupable d'un délit d'abus du droit d'elire ${ }^{85}$.

Este sistema del abogado lorenés, con su prolijidad y todo, sí que pudiera muy bien estar en el basamento de la mucho más depurada o compendiosa preferencia legislativo-criminal de 1822, con su complementario estribo sobre el delito de cohecho, mas sea esto admitido sin desvalorar, más allá del método, la adaptativa mentalidad fecundada tras el ensanchamiento objetivo de la pragmática de 1614 en la salvaguarda del meritoriaje - del orden que fuere- como canal de acceso no solo a cargos de Iglesia, sino también del rey, con la competencia regia en su provisión a modo de aglutinante. Lo seguro es que, de propia confesión, los comisionados de 1821 llevaban estudiado a Bexon y -ni que decir tiene- les asistía un conocimiento bastante, a no dudarlo, de las leyes y necesidades patrias; a partir de ahí, las proporciones en el entrevisto combinado se nos abren por el momento a los tanteos de la conjetura...

\section{Hacia el Código de 1848}

A pesar del sesgo ideológico informante de los tres proyectos ilustrados que se propusieron en los decimonónicos años treinta y a despecho del indudable referente tenido en el Código de 1822, no comparecen en ninguno de aquellos ni la inveterada simonía clerical de las leyes pretéritas ni los nombramientos ilegales para la función pública, mediando soborno o no, del corpus veinteañista, de manera que en ellos, desasistida toda represión civil de tales fraudes cuando se circuns-

83. Bexon $1807,1 . \mathrm{V}, 4^{\text {a }}$ prt., p. 88 (art. 284 , párr. $1^{\circ}$ ).

84. Bexon $1807,1 . \mathrm{V}, 4^{\text {a }}$ prt., p. 88 (art. 296).

85. Bexon 1807,1 . V, $4^{\text {a }}$ prt., p. 88 (art. 285 , párr. $1^{\circ}$ ). 
cribiesen a la esfera eclesial, tampoco se apresta una adecuada protección de la integridad y rectitud pública, con toda evidencia por defectos de plan sistemático que descuidan alguna sección de delitos cometidos por funcionarios públicos en materia del servicio. El texto preparatorio de 1830, que ni siquiera aborda el cohecho, tan solo precave que "el que cometiere alguna estafa con pretexto de facilitar el logro de algún destino u otra gracia del Gobierno [...] será castigado con cuatro años de obras públicas" que pondrán en 1834 -este borrador legislativo sigue en mucho a aquel- tope mínimo al equivalente precepto, mientras se alarga el máximo hasta los seis años ${ }^{86}$; entremedias, por el Proyecto de 1831, firmado por Sainz de Andino, semejantes conductas hubieran debido reconducirse a un inespecífico cohecho $^{87}$.

En las actas de la Comisión sobre Código Penal que estuvo reuniéndose entre los otoños de 1844 y 1845, germen de lo que llegaría a ser el texto legal positivado en 1848, se ve nacer la elección que al cabo accederá al ordenamiento: en la parte correspondiente -Título de los funcionarios públicos-, redactada con la colaboración eventual de otros compañeros por el doctor en Leyes José María Claros Jari$10^{88}$, se somete a la asamblea, sin asomo de desavenencia alguna, la contravención tocante a los nombramientos ilegales, pero todavía no lleva asociado, con expreso envío, el cohecho como posible señuelo comisivo ${ }^{89}$. Por supuesto, no queda ya ni la evocación, en buena sistemática, "[...] del delito de simonía, puramente eclesiástico, y que no creemos que debe figurar en un código penal" 90 , en palabras de 1843 de Gómez de la Serna y Montalbán, haciendo suyas las ya entendidas por los diputados de 1821 en trance de repudiar aquellas leyes y títulos intempestivos en el dia ${ }^{91}$, rechazo que no parece compartir el abogado Galilea en punto a simonía, "[...] sobre cuya penalidad nos han dejado algun tanto satisfechos las disposiciones legislativas" por estos mismos años de gestación técnica de la nueva ley penal unificada (su Examen filosófico-legal de los delitos se publica en 1846), “[...] porque verdaderamente advertimos bastante relacion entre este crímen y la pena" prescrita por el ordenamiento patrio ${ }^{92}$ :

[...] las potestades eclesiástica y temporal son diferentes en todo, y les son peculiares los medios de reprimir á los hombres; cada una de ellas tiene, por decirlo así, su esfera particular, dentro de la cual no solo la es lícito sino necesario y conveniente el ejercitar su movimiento; pero el decoro y buena armonía de ambas exije igualmente que no invada la una el terreno de la otra. Ademas el interés que tiene la potestad eclesiástica en proscribir este y todos los otros delitos de la sociedad,

86. El Proyecto de Código Criminal de 1830, art. 264. El Proyecto de Código Criminal de 1834, art. 369 .

87. El Proyecto de Código Criminal de 1831 de Sainz de Andino, arts. 732 a 736, 741 a 746.

88. Véanse Sánchez Marroyo 2013, pp. 1143-1208; Iñesta Pastor 2011, pp. 83-86, 255-256.

89. En "Actas de la Comisión General de Codificación sobre Código Penal (1844-1845)", a. 41, ses. 19-VI-1845, p. 926; a. 43, ses. 22-VI-1845, pp. 943-946; a. 622, ses. 15-XII-1845, p. 1073.

90. Gómez de la Serna, Montalbán 1843, t. II, p. 316.

91. Diario de las Sesiones..., t. I, apd. al n 38 , ses. 1-XI-1821, p. 483; también ibidem, t. III, $n^{\circ}$ 129, ses. 1-II-1822, p. 2099.

92. Galilea 1846, pp. 324-325. 
le tiene asimismo la potestad terrena; y usando cada cual de sus armas naturales aparecerá de manifiesto el apoyo que mútuamente se prestan ${ }^{93}$.

Sin dar pie a mutuo apoyo alguno, antes bajo principios de firme escisión y tras numerosas intervenciones y vicisitudes, ese Código resultante en 1848 perfecciona y consolida aquella laica opción que se ensayara en $1822^{94}$, corregido ahora con suspensión y multa de tanto a tanto "el empleado público que a sabiendas propusiere ó nombrare para cargo público á persona en quien no concurran los requisitos legales $[\ldots]^{195}$ (entre ellos, por descontado, los de una selección en regla), mas esto sin mediar cohecho, porque luego y aparte recibirá oportuna agravación "el empleado público que por dádiva ó promesa cometiere [...]" tales irregularidades, acreedor entonces a inhabilitación absoluta perpetua e incrementada multa proporcional ${ }^{96}$; en paralelo, “el sobornante será castigado con las penas correspondientes [...] á los cómplices, excepto las de inhabilitacion y suspension"97, además de que "en todo caso caerán las dádivas en comiso" ${ }^{98}$. Todo esto - enjuicia Pacheco- "[...] era un punto que faltaba en nuestra antigua legislación, como faltaba en casi todas las legislaciones" "99: en efecto, venía el cohecho stricto sensu atenido para las Partidas o las leyes recopiladas en exclusiva al juzgador ${ }^{100}$.

De los modelos francés, napolitano y brasileño detectados por los investigadores para 1848, destaca la influencia genérica del primero, ya presente en $1822^{101}$, mas en punto a nombramientos ilegales, Pacheco tan solo proporciona la concordancia con el Código del Brasil de 1830, del cual consta asimismo la consanguinidad con el español del Trienio $^{102}$ y de cuya correspondiente cláusula muy bien pudo beber para dirigir su vindicta contra "[...] los empleados públicos que por afección, odio, condescendencia, o movidos por intereses personales [...] nombren o propongan para un empleo a personas que les conste carecen de los requisitos legales" 103 , si bien juzgándolos prevaricadores en consideración del abanico motivacional que adiciona, ante lo cual corra la hipótesis con idénticas reservas a las que saldaban la pesquisa alrededor de la inspiración de 1822. Esto, por lo que atañe a los nombramientos ilegales, cuya perpetración se dirá canalizada mediante cohecho cuando un aliciente lucrativo haya determinado al responsable en su desvío de la legalidad: ganancia material indebida, por consiguiente, a cambio, no de bienes espirituales, sino de bienes públicos, de cosas -cargos- estatales... A fin

93. Galilea 1846, p. 324.

94. Véase Iñesta Pastor 2011, pp. 676-677.

95. Código Penal de 1848, art. 281.

96. Código Penal de 1848 , art. 305 , párr. $1^{\circ}$.

97. Código Penal de 1848, art. 307, párr. $1^{\circ}$.

98. Código Penal de 1848, art. 308.

99. Pacheco 2000, p. 883.

100. Las siete Partidas, III.22.24-27; Novísima recopilación, XI.1.7-9.

101. Pónganse en relación Alvarado Planas 1994, pp. 75-76; 2017, pp. 156-157, 159-160; Masferrer 2018, pp. 193-242; Iñesta Pastor 2011, pp. 294-297, 676, 678; id. 2016, pp. 245-259; id. 2018, pp. 243-278.

102. V. gr., Quintano Ripollés 1953, p. 96; Iñesta Pastor 2011, p. 296.

103. Compruébese en Pacheco 2000, p. 883 (art.129 del Código del Brasil). 
de cuentas, como lo expresa Vilanova y Mañes, los amaños del cohecho "[...] son unas imágenes de la simonía", solo que, una vez desacralizados, “[...] tan nocivos á la causa pública, como dignos de la detestación de nuestras leyes"104, de la detestación penal y, perfectivamente, de la regularización administrativa, conforme implementa y explica en su exposición de motivos y elevación a la reina cierto real decreto de 18 de junio de 1852:

Ni V. M., ni sus Ministros, reputan la facultad de nombrar los empleados como un derecho establecido para su particular conveniencia, sino que lo consideran, por el contrario, como un deber de difícil cumplimiento que obliga á buscar cuidadosamente las personas mas á propósito para el desempeño de los cargos públicos. Para regularizar cual conviene el ejercicio de esta facultad, urge fijar definitivamente las bases generales, segun las que han de verificarse el ingreso y los ascensos en todos los servicios de la Administracion activa del Estado.

[...]

Una deplorable experiencia ha venido á demostrar que el no exigir requisitos y condiciones necesarias para la entrada en la carrera de la Administracion, equivalia á constituir los destinos en patrimonio del favor, y á convertir por otra parte la práctica en ciega rutina ${ }^{105}$.

La superación del Antiguo Régimen se resuelve en un complejo, poliédrico proceso pleno de facetas y aristas. Los aprestos antisimoniáticos del legislador -pongamos por caso- penetran en el siglo XIX sostenidos aún dentro del ordenamiento español; desde luego, la tendencia laicizadora que característicamente opera en el proceso codificador supondrá el retraimiento en dicha represión, pero de alguna manera, entre tradición y reformismo ${ }^{106}$, su objeto quintaesenciado va a buscar otras formas acreedoras al interés penal del flamante Estado burgués. De los tres empeños caudales afrontados por la Codificación penal, al secularizante -los otros, el sistematizador y el humanitarista $-{ }^{107}$ responde sin ningún género de dudas el proceso aquí y así evacuado: la simonía no ha logrado siquiera reacomodarse para defensa del nuevo orden liberal, como sí han hecho o harán el cisma o la apostasía, el sacrilegio o la blasfemia, la sodomía e incluso -en azaroso zigzagueo- la controvertida usura... Cierto que de la represión de la simonía se ocupó con lógica preeminencia la propia institución eclesiástica y que, por ende, le era más sencillo al ordenamiento secular desembarazarse de estas leyes intempestivas que de otras, pero además al Estado liberal no le servía en este punto la simple reformulación, como en aquellos otros, del cálculo de política criminal con preterición de teologías y sin cuidado de otra moralidad que la pública, abocando a la atracción o apropiación de las heredadas figuras delictivas de lesa majestad pro domo sua, en salvaguarda y cumplimiento de sus exclusivos intereses. Para que

104. Vilanova y Mañes 1807, t. III, p. 107.

105. "Real decreto, fijando las bases que han de observarse para el ingreso y ascenso en todos los empleos de la Administracion activa del Estado", de 1852, preámbulo.

106. Véase Masferrer Domingo 2003, pp. 188-191.

107. Masferrer Domingo 2017, p. 32. 
la simonía le resultase de alguna utilidad había que ir más allá, preciso era desacralizarla, redirigirla y hasta renombrarla: manteniendo formas de herejía, cisma o apostasía se artillaba la Constitución política confesionalmente concebida; conservando sacrilegios, blasfemias y sodomías eran el orden y tranquilidad pública o las buenas costumbres lo favorecido; incluso la vitanda usura de otros tiempos, cuya punición parecía socavar en principio la libertad de contratación y la propiedad privada, tan caras a la burguesía liberal, acabó por traslucir la conveniencia de su revisión; pero un reciclaje de la tipicidad simoniaca había de pasar sin vuelta de hoja por desentenderse de preservar o sanear la pulcritud de las promociones e investiduras en el medio levítico, afán en el que ninguna ganancia estimulaba a la sociedad civil, y preciso era enfilar otro objeto urgido de protección y valioso en efecto: cabalmente, esas imágenes de la simonía captadas por Vilanova como materia criminal.

De la novedad introducida nos ha avisado Pacheco al hacer hincapié en que el control en vía penal de los nombramientos ilegales para cargo o empleo público "[...] faltaba en nuestra antigua legislación" y era así - como en casi todas-porque la venalidad y patrimonializacion de oficios reales llegó a institucionalizarse durante los siglos de la Monarquía Absoluta tanto por perentoriedades financieras de la administración como por la confluyente demanda social en aras de una osmótica movilidad a lo largo del espectro estamental ${ }^{108}$ (factor este de la más compleja existimación, en virtud del enmarañamiento conceptual que emana de la transmisión venal de cargos en la precontemporaneidad y el peligro de transposición de categorías y éticas hodiernas en el rastreo de lo reprobable o disfuncional) ${ }^{109}$; por otra parte, también porque a veces el responsable no ya último, sino propiamente directo hasta del nombramiento de ciertos oficiales o agentes ínfimos de la corte lo era el mismísimo soberano, como consta de Felipe $\mathrm{II}^{110}$; y el control interno, la transparencia administrativa no estaban, en fin, en el mayor desarrollo, qué duda cabe... En resumidas cuentas, siglo XIX adelante ya no convenía sino desoír los consejos de Bentham en pro de la explotación económica de esta utilidad pública y mucho menos cuadraba tolerar granjerías privadas a costa del Estado en cuya maquinación y provecho entrasen sus mismos servidores; antes bien, con vistas al aspirado fortalecimiento estatal hubo de parecer lo más certero rodear la función pública de una aureola de intangibilidad análoga a la que históricamente envolviera órdenes y ministerios eclesiásticos, gracias ante todo -aflojado el freno moral de la conciencia- al indefectible refuerzo punitivo.

108. Consúltense, v. gr., Lalinde Abadía 1970, pp. 91, 98-109; Domínguez Ortiz 1970, pp. 105137; Tomás y Valiente 1982, pp. 151-177; Cuartas Rivero 1984, pp. 495-516; García Marín 1986, pp. 178-191; o Jiménez Estrella 2012, pp. 259-272.

109. Atiéndase, v. gr., a Dedieu, Artola Renedo 2011, pp. 29-45.

110. V. gr., Escudero 2002, pp. 535-540. 


\section{FUENTES Y BIBLIOGRAFÍA CITADA}

"Actas de la Comisión General de Codificación sobre Código Penal (1844-1845)", en Lasso Gaite, Juan Francisco (1970), Crónica de la Codificación española. 5. Codificación penal, Madrid, v. II, pp. 459-1105.

Alier, Lorenzo María (1910), "Simonía”, en Enciclopedia Jurídica Española, Barcelona, t. XXVIII, pp. 782-784.

Alvarado Planas, Javier (1994), "La codificación penal en la España isabelina: la influencia del código penal del Brasil en el código penal español de 1848", en Martínez Ruiz, Enrique (coord.), España en la época de la fundación de la Guardia Civil: V Seminario Duque de Ahumada, Madrid, pp. 43-82.

Alvarado Planas, Javier (2017), "Influencias brasileñas, francesas, italianas y austriacas en el Código Penal español de 1848", en Masferrer, Aniceto (ed.), La codificación penal española. Tradición e influencias extranjeras: su contribución al proceso codificador (parte general), Cizur Menor, pp. 109-163.

Álvarez, José María (1827), Instituciones de Derecho real de Castilla y de Indias, Nueva York.

Álvarez Posadilla, Juan (1802), Práctica criminal por principios, ó modo y forma de instruir los procesos criminales de las causas de oficio de justicia, Valladolid.

Dedieu, Jean Pierre; Artola Renedo, Andoni (2011), "Venalidad en contexto. Venalidad y convenciones políticas en la España moderna", en Andújar Castillo, Francisco; Felices de la Fuente, María del Mar (eds.), El poder del dinero: ventas de cargos y honores en el Antiguo Régimen, Madrid.

Antón Oneca, José, (1965), "Historia del Código Penal de 1822”, Anuario de Derecho Penal y Ciencias Penales 18.2, pp. 263-278.

Asso y del Río, Ignacio Jordán de; Manuel y Rodríguez, Miguel de (1805), Instituciones del Derecho civil de Castilla, Madrid.

Bentham, Jeremías (1821), Principios de la ciencia social ó de las ciencias morales y políticas, ed. Toribio Núñez, Salamanca.

Bentham, Jeremías (1834), Principios de legislacion y de codificacion, extrc. Francisco Ferrer y Valls, Madrid.

Bentham, Jeremías (1838), Teoría de las penas y de las recompensas, extrc. Estevan Dumont, trad. L. B., Barcelona.

Berní, Joseph (1749), Practica criminal, Valencia.

Bexon, Scipion (1807), Application de la théorie de la législation pénale, ou code de la sureté publique et particulière, París.

Casabó Ruiz, José Ramón (1969), “Los orígenes de la codificación penal en España: el plan de Código criminal de 1787”, Anuario de Derecho Penal y Ciencias Penales 22.2, pp. 313-342.

Cavalario, Domingo (1841), Instituciones del Derecho Canónico, trad. Juan Tejada y Ramiro, Valencia.

Código penal francés, traducido al castellano por orden de S. M. el emperador Maximiliano I (1866), trad. Manuel Zavala et al., Méjico. 
“Código Penal francés de 1791” (2009), trad. José Luis Guzmán Dalbora, Revista de Derecho Penal y Criminología 1, pp. 487-517.

Los Códigos españoles concordados y anotados (1847/51), Madrid, t. I.

Cornejo, Andrés (1779), Diccionario histórico, y forense del Derecho real de España, Madrid.

Cuartas Rivero, Margarita (1984), "La venta de oficios públicos en Castilla-León en el siglo XVI”, Hispania 158, pp. 495-516.

Diario de las Sesiones de Córtes. Legislatura Extraordinaria 1821-1822 (1871), Madrid.

Diccionario de Derecho canónico arreglado a la jurisprudencia eclesiástica española antigua y moderna (1854), París.

Domínguez Ortiz, Antonio (1970), "La venta de cargos y oficios públicos en Castilla y sus consecuencias económicas y sociales", Anuario de Historia Contemporánea y Social 3, pp. 105-137.

Dou y de Bassóls, Ramón Lázaro de (1800/02), Instituciones del Derecho público general de España, con noticia del particular de Cataluña y de las principales reglas de gobierno en qualquier estado, Madrid.

Echebarría y Ojeda, Pedro Antonio (2006), Los delitos y las penas en el Diccionario de Echebarría de 1791, eds. Borja Mapelli Caffarena y Antonio García Benítez, Sevilla.

Elizondo, Francisco Antonio de (1779), Práctica universal forense de los tribunales de España, y de las Indias, Madrid.

Escriche, Joaquín (1838/45), Diccionario razonado de legislacion y jurisprudencia, Madrid.

Escudero, José Antonio (2002), Felipe II: el Rey en el despacho, Madrid.

Febrero, Joseph (1769/81), Librería de escribanos, é instruccion jurídica teorico práctica de principiantes, Madrid.

Fernández de Andrada, Andrés (1993), “Epístola moral a Fabio” y otros escritos, ed. Dámaso Alonso, Barcelona.

Filangieri, Cayetano (1821/22), Ciencia de la legislacion, trad. Juan Ribera, Madrid.

Galilea, Alejo (1846), Exámen filosófico-legal de los delitos, Madrid.

García Goyena, Florencio; Aguirre, Joaquín (1842), Febrero, ó Librería de jueces, abogados y escribanos, comprensiva de los Códigos civil, criminal y administrativo, tanto en la parte teórica como en la práctica, con arreglo en tu todo á la legislacion hoy vigente, Madrid.

García Goyena, Florencio (1843), Código criminal español segun las leyes y práctica vigentes comentado y comparado con el Penal de 1822, el francés y el inglés, Madrid.

García Marín, José María (1986), La burocracia castellana bajo los Austrias, Alcalá de Henares.

Giménez Carrillo, Domingo Marcos (2011), “La venta de hábitos de las órdenes militares en el siglo XVII", en Andújar Castillo, Francisco; Felices de la Fuen- 
te, María del Mar (eds.), El poder del dinero: ventas de cargos y honores en el Antiguo Régimen, Madrid.

Gómez de la Serna, Pedro; Montalbán, Juan Manuel (1843), Elementos del Derecho civil y penal de España, Madrid.

Gutiérrez, Josef Marcos (1824), Practica criminal de España, Madrid.

Gutiérrez Martín, Luis (1967), El privilegio de nombramiento de obispos en España, Roma.

Iñesta Pastor, Emilia (2011), El Código Penal Español de 1848, Valencia.

Iñesta Pastor, Emilia (2016), "The influence of the 1819 Criminal Code of the

Two Sicilies upon the Spanish criminal law codification ad the parliament of the Nineteenth Century", en Romano, Andrea (ed.), Culture parlamentari a confronto. Modelli della rappresentanza política e identità nazionali, Bologna.

Iñesta Pastor, Emilia (2018), "The influence exerted by the Criminal Code of the

Two Sicilies upon Nineteenth-Century Spanish Criminal law codification and its projection in Latin America", en Masferrer, Aniceto (ed.), The Western Codification of Criminal Law: a revision of the myth of its predominant French influence, Cham (Schweiz).

Jiménez Estrella, Antonio (2012), "Poder, dinero y ventas de oficios y honores en la España del Antiguo Régimen: estado de la cuestión”, Cuadernos de Historia Moderna 37, pp. 259-272.

Lalinde Abadía, Jesús (1970), Los medios personales de gestión del poder público en la historia española, Madrid.

Larraga, Francisco (1860), Prontuario de Teología Moral, Barcelona.

"Ley del Código Penal", de 8 de junio de 1822, en Coleccion de los Decretos y Órdenes Generales Expedidos por las Córtes 9, decr. 56, pp. 211-381.

Las Leyes de Recopilacion (1772), Madrid.

Maqueda Abreu, Consuelo (1997), "Conflictos jurisdiccionales y competencias en la Castilla del siglo XVII. Un caso ilustrativo", Anuario de Historia del Derecho Español 67, pp. 1669-1588.

Martínez, Manuel Silvestre (1791), Librería de jueces, utilísima y universal, Madrid.

Masferrer Domingo, Aniceto (2003), Tradición y reformismo en la Codificación penal española: hacia el ocaso de un mito. Materiales, apuntes y reflexiones para un nuevo enfoque metodológico e historiográfico del movimiento penal europeo, Jaén.

Masferrer Domingo, Aniceto (2018), "The myth of French influence over Spanish codification: the general part of the Criminal Codes of 1822 and 1848”, en id. (ed.), The Western Codification of Criminal Law. A revision of the myth of its predominant French influence, Cham, 2018, pp. 193-242.

Masferrer Domingo, Aniceto (2017), “Tradición e influencias extranjeras en la Codificación penal española", en id. (ed.), La codificación penal española. Tradición e influencias extranjeras: su contribución al proceso codificador (parte general), Cizur Menor, pp. 27-56. 
Montalbán, Juan de (1720), Cartas pastorales de usura, simonia, y penitencia, para confessores y penitentes, Salamanca.

Novísima recopilación de las Leyes de España (1805), Madrid.

Pacheco, Joaquín Francisco (2000), El Código Penal concordado y comentado, ed. Abel Téllez Aguilera, Madrid.

Perez y Lopez, Antonio Xavier (1791/98), Teatro de la legislacion universal de España é Indias, Madrid.

El Proyecto de Código Criminal de 1830 (1978), ed. José Ramón Casabó Ruiz, Murcia.

El Proyecto de Código Criminal de 1831 de Sainz de Andino (1978), ed. José Ramón Casabó Ruiz, Murcia.

El Proyecto de Código Criminal de 1834 (1978), ed. José Ramón Casabó Ruiz, Murcia.

Quintano Ripollés, Antonio (1953), La influencia del Derecho español en las legislaciones hispanoamericanas, Madrid.

Ramos Vázquez, Isabel; Cañizares Navarro, Juan Benito (2014), "La influencia francesa en la primera codificación española: el Código penal francés de 1810 y el Código penal español de 1822", en Masferrer, Aniceto (coord.), La codificación española: una aproximación doctrinal e historiográfica a sus influencias extranjeras, y a la francesa en particular, Madrid.

"Real decreto, fijando las bases que han de observarse para el ingreso y ascenso en todos los empleos de la Administracion activa del Estado", de 18 de junio de 1852, en Coleccion Legislativa de España 56 (2 cuatrim. 1852), disp. 493, pp. 173-182.

"Real decreto, mandando que el Código penal y la ley provisional que dicta las reglas oportunas para la aplicacion de sus disposiciones, se observen como ley en la Península é Islas adyacentes desde el dia $1^{\circ}$ de Julio del corriente año", de 19 de marzo de 1848, en Coleccion Legislativa de España 43 (1프 cuatrim.), disp. 163, pp. 206-305.

Recopilacion de las Leyes destos Reynos (1640), Madrid.

Rieger, Pablo José de (1841), Instituciones de jurisprudencia eclesiástica, trad. Joaquín Lumbreras, Madrid.

Sala, Juan (1832), Ilustracion del Derecho real de España, Imprenta Real, Madrid. Sánchez Marroyo, Fernando (2013), "Empresa agraria, crédito privado y tradicionalismo político. Esplendor y ocaso de uno de los más poderosos terratenientes de la España del XIX, José María Claros Jarillo", Revista de Estudios Extremeños 69.2, pp. 1143-1208

La Santa Biblia (1981), trad. Evaristo Martín Nieto et al., Madrid.

Las siete Partidas del Rey Don Alfonso el Sabio, cotejadas con varios códices antiguos por la Real Academia de la Historia (1807), Madrid.

Las siete Partidas del sabio Rey don Alonso el nono (1555), ed. Gregorio López, Salamanca. 
Tapia, Eugenio de (1837), Febrero novísimo, ó Librería de jueces, abogados y escribanos, refundida, ordenada bajo nuevo método, y adicionada con un tratado del juicio criminal, y algunos otros, Valencia.

Tomás y Valiente, Francisco (1982), "Ventas de oficios públicos en Castilla durante los siglos XVII y XVIII", Gobierno e instituciones en la España del Antiguo Régimen, Madrid, pp. 151-177.

Valle Linacero, Félix del; Chavarría y Montoya, Antonio de (1840), Leyes penales vigentes actualmente en España, recopiladas de nuestros códigos, ordenanzas y colecciones de decretos. Reflexiones sobre los vicios de la administracion de Justicia, abusos de algunos curiales, y necesidad de una pronta y eficaz reforma de nuestros Códigos, Madrid.

Vilanova y Mañes, Senén (1807), Materia criminal forense, ó tratado universal teórico y práctico, de los delitos y delinquentes en género y especie, para la segura y conforme expedicion de las causas de esta naturaleza, Madrid.

Vizcaíno Pérez, Vicente (1797), Codigo y práctica criminal, arreglado a las leyes de España, Madrid. 